\title{
Archaeologia
}

http://journals.cambridge.org/ACH

Additional services for Archaeologia:

ARCHAEOLOGIA:

MISCELLANEOUS TRACTS

ANTIQUITY.

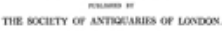

VOLEXX $x$.

Email alerts: Click here

Subscriptions: Click here

Commercial reprints: Click here

Terms of use : $\underline{\text { Click here }}$

\section{Remarks on the Manner of the Death of King Richard the Second. By P.W. Dillon, Esq. of Paris; In two Letters addressed to Sir Henry Ellis, K.H., F.R.S., Secretary}

P.W. Dillon

Archaeologia / Volume 28 / Issue 01 / January 1839, pp 75 - 95

DOI: 10.1017/S0261340900000369, Published online: 12 June 2012

Link to this article: http://journals.cambridge.org/abstract_S0261340900000369

How to cite this article:

P.W. Dillon (1839). VI. Remarks on the Manner of the Death of King Richard the Second. By P.W. Dillon, Esq. of Paris; In two Letters addressed to Sir Henry Ellis, K.H., F.R.S., Secretary. Archaeologia, 28, pp 75-95 doi:10.1017/S0261340900000369

Request Permissions : $\underline{\text { Click here }}$ 


\section{Remarks on the Manner of the Death of King Richurd the Second. By P. W. Duluon, Esq. of Paris; In two Letters addressed to Sir Henry Ellis, K.H., F.R.S., Secretary.}

Read 15th and 29th November, 1838.

\section{Dear Sir,}

I HAVE read with a deep interest the able Dissertations of two of your learned colleagues, Messrs. Webb and Amyot, on that oft controverted point of English history the death of Richard the Second.a Both reject the popular account of his murder, by Sir Piers Exton and accomplices, as comparatively unfounded; and maintain, with Thomas of Otterbourn, Hardyng, and, it must be confessed, nearly all the contemporary chroniclers, that he died of starvation.

So far Messrs. Webb and Amyot agree in their conclusions, but so far only. When they proceed to inquire whether this starvation was voluntary or not, each adopts a different hypothesis. Mr. Amyot adduces a variety of arguments, in order to shew that it was completely voluntary on the part of Richard; while Mr. Webb attributes it to the cruel mandates of Henry the Fourth alone.

Nor are these the only opinions to which this subject has of late given rise. Mr. Tytler, ${ }^{b}$ in his History of Scotland, a work of considerable talent and research, hesitates not to pronounce all the accounts of Richard's death in the castle of Pontefract, whether from voluntary or compulsory starvation, from the sword, or otherwise, so many fables; he having escaped into 
Scotland, where he was maintained for several years at great expense, by the Regent of that kingdom, the Duke of Albany. A statement of so novel and startling a nature required evidence of no ordinary kind; and it is but justice to Mr. Tytler to admit, that he has enrolled several respectable authorities in its favour. Even Sir Walter Scott, we are assured, looked upon Mr. 'Tytler's account as much more credible than any other on the same subject.c

Having enumerated the different hypotheses which prevail with regard to the manner of King Richard's death, it only remains for me to proclaim my own. Nor do I fulfil this duty without a degree of hesitation; for, however strongly convinced of the authenticity and truth of the evidence I am about to adduce in support of my opinion, the very fact of its being directly opposed to such respectable authorities makes me fear lest it should be received with contempt or mistrust. As, however, the premises with which I start, are totally different from those of my forerunners on this question, it may appear less presumptuous on my part to come forward with different conclusions.

I shall begin by proclaiming myself a decided partizan of the old, though now almost exploded opinion, that Richard was assassinated in his prison by Sir Piers Exton. But, before I proceed to my proofs, I must beg leave to avail myself of a privilege which has been unsparingly exercised by all who have discussed this topic before me, namely, that of subverting, or doing my utmost to subvert, every statement opposed to my own.

We have just seen that these statements have been reduced in these latter times to three. Richard died of voluntary abstinence-Mr. Amyot's statement. He died of compulsory starvation-Mr. Webb's. And, lastly, he escaped into Scotland-Mr. Tytler's version. In order to refute the latter hypothesis, with which I shall begin, one thing alone is necessary: it must be shown that, at the very period when the reports of Richard being alive in Scotland were strongest, an inquiry was set on foot, with a view of ascertaining the fact, by the King of France; and that this inquiry, although conducted by one who knew Richard well, and who believed, himself, in the

' See Archæolog. vol. XXV. 
reports, ended in disappointment. This refutation I am able to give from authentic and irrefragable evidence.

I had the good fortune to discover, a few weeks ago, in the Royal Library of Paris, two documents connected with Creton, the author of a metrical history of the deposition of Richard, of which a transcript was published by Mr. Webb, in the twentieth volume of the Archæologia. The first is an order or mandement from King Charles the Sixth of France to Jehan or John Creton, his valet-de-chambre, prescribing the payment of 200 francs to the said Creton, for a voyage to Scotland, in order to see if Richard the Second were alive, as was reported.

The second contains Creton's receipt for one hundred of the two hundred francs specified above, which he acknowledges to have been granted to him as a recompense for having gone to Scotland to ascertain whether Richard were alive in that kingdom, "comme on disoit," as had been reported. Both documents are on parchment; both are of unquestionable authenticity.

We have here a proof, than which nothing can be more irrefragable, that in 1410 , for the documents in question bear that date, a messenger had returned from Scotland, whither he had been sent by the Court of France, for the express and sole purpose of inquiring into the truth of the reports of King Richard's being alive. And who was the messenger selected for that mission? Jehan Creton, the King of France's valet-de-chambre, who had formerly been a member of Richard's household; who had followed him into Ireland on the occasion of his fatal expedition against the tribes of that country; who had heard his piteous lamentations, when betrayed into the hands of Henry of Lancaster; who had published on his return to France a circumstantial account of all these events ; and, lastly, who disbelieved from the beginning the various stories of Richard's death. It must be admitted that Creton was of all others the most fitting person for such a mission.

But, were Creton's expectations realized? Did he find Richard alive and in safety in Scotland? With regard to these points our documents are silent; at least, they contain no direct information. It may indeed be inferred from their very silence, that Creton's voyage ended in disappoint- 
ment. Had he discovered Richard, some trace of the discovery would have remained; the indemnity granted to him would have been greater, and that poetic spirit with which he was so deeply imbued, and of which there are memorable records still extant, would have burst forth anew, and embodied itself in some congratulary Ode or Ballad. We have nothing, however, of the kind; on the contrary, Creton's conduct, as well as that of Charles the Sixth, seems to announce, that the individual who personated Richard in Scotland, turned out to be an impostor ; for we find Richard's widow, Queen Isabella, granted in marriage to the Duke of Orleans shortly after Creton's return. Indeed I am inclined to think that it was not a chivalrous feeling of affection alone for the deposed monarch that prompted the French Court to take such pains in order to sift the matter to the bottom. The marriage of the Duke of Orleans with Queen Isabella, which was on the tapis so early as 1403 , was ratified, as I shall show hereafter, immediately after Creton's return; a proof that political motives had something to do with his mission to Scotland.d

But, as I have other and more positive arguments to bring forward, I can afford to sacrifice such indirect evidence as might result from an ingenious twisting of these striking considerations. If I can appeal to the express and positive testimony of Creton himself; if I can shew that he declared on his return that Richard was no more; I shall have given a demonstration which scepticism itself cannot cavil with. This I am fortunately able to do. In the manuscript volume of the Royal Library, which I have already alluded to as containing Creton's epistle to Richard the Second, we find another addressed by the same to Philip Duke of Burgundy, in which it is positively asserted that Richard met with a violent and bloody end. Indeed, his object in this new epistle is to incline the Duke " to avenge the death of that good Catholic King Richard, whose blood was shed so traitorously and feloniously, that it is a lamentable thing to hear." $\mathrm{e}$

But here a difficulty presents itself. Philip Duke of Burgundy, whom

a This conjecture is confirmed by the authority of Biondi and Sir James Mackintosh. See Archæol. vol. XXIII. p. 293.

e See page 95 . 
Creton addresses on this occasion, died in 1404, six years before the date of those documents which attest that Creton made a journey to Scotland. Consequently, this epistle addressed to the Duke cannot contain any eridence relative to the information which Creton may have gathered in that country. Moreover, his letter to Richard, in which he apostrophises him as still alive, was written in 1405 : how then are we to reconcile so many and such palpable contradictions ?

I confess that these objections startled me a good deal at first; it was only after having carefully analysed the different documents alluded to, that I was able to discover a satisfactory explanation. In the first place, Mr. Tytler has committed a palpable error, in asserting that Creton's letter to Richard was written in 1405 . Had he perused it attentively, he would have seen that it bears primd facie evidence of having been penned prior to 1404. We have in the thirty-sixth volume of the French Collection of Manuscripts, known by the appellation of Brienne, a marriage contract between Queen Isabella, Richard's relict, and the Duke of Orleans, bearing date 1404; whereas Creton speaks of her, in this letter to Richard, as being still a pucelle, that is, a virgin, "aussi chaste et entière que lorsque tu partis d'elle à Windesor pour aller en ton voyage en Irlande." $f$ (She is as chaste and pure as when you left her at Windsor to go into Ireland.) This passage evidently proves that the memorable expression of Creton's belief in Richard's safety was anterior to Queen Isabella's marriage, and consequently before the year 1404. On the other hand, the second epistle, addressed to the Duke of Burgundy, as is obvious from one or two sentences, was written in 1402 . Creton speaks therein of the inhabitants of Brittany as disposed to recognize the Duke of Burgundy for their Regent. He also alludes to the lamentable state of the church, rent and torn by internal dissensions. Now these two allusions can only correspond with the year 1402, g when Philip of Burgundy, immediately after the Duchess of Brittany's marriage with Henry the Fourth of England, was promoted to the regency of that State, and the Pope, or Antipope, Benedict XII. resumed

f See page $89 . \quad \mathrm{g}$ Dom Morice, Hist. de Bretagne, tom. i. p. 432. 
the pontifical robes, which he had resigned, and threw the whole Christian world into a state of confusion.

I think myself justified in drawing the following conclusions from the premises which I have laid down. $1^{\circ}$. Early in 1402, it was believed by Creton and the French Court that Richard was alive in Scotland; the first letter and congratulatory ode were written about that period; at any rate they were written prior to Creton's voyage, for he announces at the end of his first epistle his intention ${ }^{\mathrm{h}}$ to undertake a voyage soon, in order to see his beloved lord Richard once more. $2^{\circ}$. Creton returned from Scotland about the latter end of the same year; on which occasion he addressed the Duke of Burgundy in a second epistle, beseeching him to avenge Richard's death; an infallible proof of his having discovered that the individual who personated Richard in Scotland was an impostor.

There only remains one point to explain. Why, it will be asked, if Creton returned from Scotland so early as 1402, was he compelled to wait so long as the year 1410 for the payment of the indemnity due for his trouble? Surely the King of France would never have allowed his faithful valet-de-chambre to be treated with so much neglect. This difficulty can be easily explained. Charles the Sixth had only occasional glimmerings of reason. During his habitual state of insanity, the administration of affairs was wholly in the hands of a factious band of relations, who were engaged in an incessant and sanguinary struggle for superiority, that prevented them from attending to other concerns. History tells us, that, about the period alluded to, id est, from 1401 to 1410 , Charles was tormented by one of those fits of mental aberration which we have just noticed. Thence the apparent neglect with which the just claims of Creton were treated.

n This fact suffices alone to prove that Creton's letter to Richard was written before his pathetic appeal to the Duke of Burgundy, in whieh he beseeches that Prince to avenge Richard's death. It would be absurd to suppose that any thing short of ocular proof could have effected such a total revolution in Crecon's feelings as these two letters indicate. In the first he seems confident of Richard's safety, and declares that he is on the point of crossing the sea to offer him his homages, when, lo! we meet on the very next page another epistle, written about the same time, in which he calls upon the French nobility to avenge his death. 
But if we turn for a moment to the two important documents in which Creton's name is mentioned, we shall find a further confirmation of this view of the matter. In the first, King Charles speaks of the voyage as having taken place a long while ago (piéça.) The word pieça is always used in this sense by the writers of the 13th, 14th, and 15th centuries, as may be shewn by a multitude of examples. The two following will suffice:-

Or vous dirai que vous ferez, Une grant pieça vous tiendrez, Du fort Chastel allez voir.

Roman de la Rose.

Et si vous di bien sans mentir, Qu'Amors fut grant pieça perdue, Si par un clerc ne fust maintenue.

Fabliau du Jugement d'Amors.

But this is not all. In the letter itself this meaning is clearly pointed out. The following sentence which I transcribe ${ }^{i}$ may be viewed as a commentary on the word pię̧a.- "Pour lequel voyaige faire, nous ne feïsmes aucune chose pour lors, ni depuis au dit Creton bailler, ni aussi n'a eu de ce de nous aucunes lettres, si comme de ce avons été souffisamment informés." (For which voyage we granted nothing to the said Creton at that time nor since; neither has he obtained from us on that account any letters, as we have been sufficiently informed.)

I think it unnecessary to dwell at greater length on Mr. Tytler's statement, nor to call your attention to an additional Complainte by Creton, in which he expresses, in still more energetic terms, the conviction he acquired, during his journey to Scotland, of Richard's death. I send you a faithful transcript of all the documents I have alluded to, leaving it to the learned Society I am addressing, to say how far the conclusions I have drawn therefrom are conformable to the strict rules of historical evidence.

With regard to the systems of Messrs. Webb and Amyot, I own I cannot combat them with the same advantages. With the exception of the testi-

i Page 94 .

VOL. XXVIII. 
mony of Creton, I have not as yet discovered any new evidence in opposition to their ingenious statements. However, I think that even this discovery will be considered as militating strongly in favour of the old Shaksperian version of Richard's death from violence in the castle of Pontefract.

In Creton's epistle to the Duke of Burgundy, which we have shown to have been written about the year 1402, i. e. after his return from Scotland, he distinctly and emphatically declares that Richard's blood was shed in a violent and cruel manner : ${ }^{k}$ "Après mon très redoubté Seigneur veuillez que vengeance ou punicion soit faicte du noble sang du bon Catholique, le Roi Richart, lequel a ésté espandu tant villamment, tant traitreusement que certes c'est molt misericordeuse et piteuse chose à oyr la fin de ses jours, lesquels par la vray et loyal amour qu'il avoit pardeça ont ésté finis avant que son aage deust estre accompli."-(And then, my most redoubtable lord, please to avenge and punish the death of that good Catholic, King Richard, whose noble blood has been shed in so villanous and traitorous a manner, that it is a lamentable and piteous thing to hear the end of his days ; which for the true and loyal affection he bore this kingdom were shortened before his natural term had expired.)

In reading this passage we must bear in mind that the writer formerly disbelieved the current report of Richard's death from starvation in the castle of Pontefract, thinking him still alive. That at a later period he wrote to Richard, congratulating him on his escape, and telling him that he would cross the sea shortly to offer his homages in person; that the sentiments expressed in this paragraph were those he entertained after having visited Scotland, and ascertained that the personage who personated Richard in that kingdom was an impostor or a fool. If we bear these circumstances in mind, and recollect that Creton was sent by the French Court with full powers for sifting this matter to the bottom, we cannot but admit that his testimony bears with it greater weight than the whole mass of vague and conflicting authorities which the researches of Messrs. Webb and Amyot have arrayed in favour of their opinions. Nor should we forget that Queen Isabella was given in marriage to Charles, the eldest son of the Duke of Orleans, immediately after Creton's return from Scotland. This marriage 
would not have been consummated had there remained the slightest doubt concerning Richard's death. As I observed above, the chief motive of Creton's journey was to pave the way for this event. ${ }^{\text {l }}$

There is not a single French chronicler, among all who wrote at this period, that does not declare that Richard died of a violent death. The monks of St. Denys, ${ }^{m}$ the best authority of the age, say, in express terms, that he was murdered by Sir Piers Exton. Le Laboureur, ${ }^{\mathrm{n}}$ who copied them in his history of Charles the Sixth, fully adopts their opinion. Cartier is equally positive.

Juvenal des Ursins, ${ }^{\circ}$ Archbishop of Rheims, whose life of Charles the Sixth was written about 1422, states that Richard was violently put to death. He adds, "But so many authors have given the particulars of this lamentable event, that I think it needless to dwell upon it at greater length." The testimony of Juvenal des Ursins is only second to that of Creton in importance. His father was Chancellor of France, and took part in all the leading events during the first ten years of Charles the Sixth's reign. It is chiefly with the particulars supplied by him that his son composed his narrative. No information could have been drawn from a more authentic or respectable source.

I shall not take up your time with an enumeration of the other contemporary authorities in France which I can appeal to in support of the popular

1 Since the above was written, my attention has been called to an article by Mr. Amyot in the twenty-third volume of the Archæologia, in reply to Mr. Tytler's statement, in which he dwells at some length on the importance of the evidence in favour of Richard's death, afforded by the fact of Queen Isabella's marriage. It does not, however, appear that Henry ever made a formal demand of her hand for any of his children, as Mr. Amyot asserts. It was the Princess Mary, then in the convent of Poissy, that he demanded in 1406. See Monstrelet, tom. i. chap. 34, and MSS. of Brienne, tom. xxxiv. where Henry's instructions to his ambassadors are given at length. The Princess refused to quit her convent.

m The MSS. of the Monks of St. Denys, Royal Libr. Paris, passim.

n Le Laboureur, tom. i. p. 423.

- The words of Juven. des Ursins are very remarkable: "Henry fit tant que les serviteurs du Roy Richard et auxquels il se fixit le mirent à mort inhumainement. Et pour ce que plusieurs en ceste matière eu ont écrit on s'en passe en bref. Et trouve-t-on bien les Anglais ont fait autrefois de tels exploits." Hist. de Charles VI. page 142. 
account of Richard's death. In 1402, seven French noblemen sent a formal challenge to the English Court, in which they accused the King of having traitorously put Richard to death, and demanded mortal combat against an equal number of Englishmen. The two parties met in Brittany, and the French were victorious.

We find in Brienne, vol. xxxiv. page 228, another important document relative to this controversy. It is a proclamation of Charles the Sixth, King of France, dated 1406, to the English people, calling upon them to avenge the death of King Richard. Speaking of Henry the Fourth, he says, "Qui violentan manum in eum (Ricardum) fecit, et vita privavit."-(Who laid violent hands on King Richard, and deprived him of life.) In this passage we find a new evidence of the horror which the French entertained for Henry, in consequence of their conviction that he had put Richard to death. And here it may be observed, that no consideration could prevail upon the Court of France to give to Richard's successor the title of King during the negotiation for Queen Isabella's return. The ambassadors to the English Court are expressly enjoined to call Henry Duke of Lancaster, and not King, nor Cousin. I may refer to the valuable correspondence in the thirty sixth and thirty-fourth volumes of Brienne, which I have often quoted, for some curious instances of this.

I think it unnecessary to allude to the various chronicles of Richard the Second, which are to be found in the manuscript department of the Royal Library at Paris. They have been often quoted, particularly by Messrs. Webb and Amyot, as the source from which such English and French historians, as represent Richard to have fallen by the treacherous blows of Sir Piers Exton, have drawn their statements. As long as we are in ignorance of the author of these chronicles, we cannot determine very accurately the precise degree of credibility that ought to be attached to them. That they have, however, always been regarded by the Kings of France as the first authority on this subject, is obvious from the care with which they have been preserved, and the multitudinous transcripts thereof which are still to be found in the Royal Library. One of these copies, that bearing the number 7532, formerly belonged to Charles the Ninth. It is interspersed with fragments of Creton's Metrical Account, which are quoted as so many 
confirmatory proofs. I do not despair of one day discovering the name of the author of these interesting chronicles. In the mean time, I feel myself justified in asserting, that their authority, joined to that of Creton, and all the French writers of the fifteenth century, more than counterbalances the vague, contradictory, and, in almost every instance, partial testimonies of the English writers of the same period.

I have the honour to remain, my dear Sir,

Your very obedient servant,

DILLON.

Note. The opinion that Richard died of starvation was not unknown in France, although no one partook of it. The MSS. 10,212, $3 \mathrm{C}$, alludes to it in the following words, " Pour couvrir la trayson de ceulx d'Angleterre, leur oppinion est qu'il ne mourut point par la manière devant dicte (i.e. par la main d'Exton) mais mourut aultrement." The author then proceeds to give Thomas of Otterbourne's statement: "Now Richard, on learning the death of his partisans, abstained from food for four days, at the expiration of which two priests were sent to expostulate with him. They succeeded in prevailing upon him to change his resolution, but the orifices of his stomach being closed he could not eat, and therefore died."

\section{E T T E R II.}

Dear Sir,

I HAVE taken some pains in order to collect such documents as might impart any additional information relative to Creton. Although my researches have not led to as satisfactory results as I could have wished, they enable me to add a ray or two to the light which your learned colleagues, 
Messrs. Webb and Amyot, have thrown around this interesting personage. The following act is copied verbatim from the original in the Cabinet of Gaignières, Royal Library, Paris.

"Je Jehan Creton escuyer ai reçu de Jehan Chauvel sur gaiges de moi seul ès prèsentes guerres en la compagnie et sous Robert de Clermont 15 livres Tournais. A Paris, 7 Oct. 1357." Cire rouge, un oiseau surmonte d'une rose.

If we suppose Creton to have been only twenty years old when he signed the foregoing receipt, it will follow that he had attained the age of seventythree when he was indemnified for his journey to Scotland in 1410. As this journey took place 1402, he appears to have been about sixty-five years old when his chivalrous affection for Richard prompted him to undertake it.

There is reason to believe that Creton had the misfortune to live long enough to witness the horrid anarchy into which the rivalry of two ambitious noblemen, the Dukes of Orleans and Burgundy, precipitated his country. Although a dependent of the House of Burgundy, he appears to have stood aloof from the quarrel; contenting himself with addressing to both parties sundry generous and patriotic appeals in favour of their common country. In one of the MS. volumes of the Royal Library at Paris, may be seen a ballad, or complaint, in which Creton points out the dire catastrophes that befel Rome, in consequence of the sanguinary rivalry between Marius and Sylla. He hints therein the necessity of King Charles awakening to a sense of his own interests and those of his people, and curbing at once his haughty relations. After this we hear no more of Creton. His warm-hearted account of the deposition of Richard will remain one of the most interesting records of the turbulent times he lived in. I am deeply indebted to Mons. La Cabone, the Keeper of the Genealogical Records of the Royal Library of Paris, a gentleman of the most distinguished acquirements, for the assistance he has afforded me in my researches relative to Creton.

I have the honour to remain, my dear Sir,

Your very obedient servant,

DILLON,

Employé aux travaux historiques qui se font par ordre du Gouvernement Français. 


\section{Epitre par Creton, dans laquelle il se rejouit de ce que le Roi Richard est délivré.}

"Ainsi com̃e vraye amour requiert à très noble Prince et vray Catholique Richart d'Angleterre je Creton ton lège serviteur te envoie ceste epistre et saches qu'en l'estat present l'ire de mon cuer espanoit mes larmes par mes jour pensant à ta douloureuse vie et touteffois mon esprit est moult reconforté et ay vertueuse esperance pour ta sainté. Et por ce qu'on dit par deça que tu es sains et allegies, desquelles choses Je prye Nostre Seigneur qu'ainsi soit. Helas! très redoubté Sire, et coñent a peu ton seul corps soustenir ne porter tant de doulereuse tristesse sans mort. Certes toutes les creatures qui en parlent ou ouient parler s'en esbayssent molt et la plus grant partie des hommes ne le peut croire : Mais pour ce leur peut apparoir que Nostre Seigneur Dieux qui est vrai juge toy estant es mains de tes ennemis ta tenu en sa saincte garde en toy demoustant et amères fortunes et paravanture pour esprouver la constance et l'estableté de ta ferme foy et tọy congnoissant la puissance divine. Desirant parvenir à la gloire qui est sans fin les aie portées en vraye pacience en ly rendant graces et loenges de tout ce qui ly plaist estre fait : et par ainsy apparoist que tu es amy de Dieu ou autrement ta vie fust pieça finie. Et peutêtre que ces choses te sont predestinées devant ta nativité. Or ayes doncques ferme esperance en Nostre Seigneur plus qu'oncques mais, car je sais bien que si tu es vif, maugre le traistre de Lencastre et toutes ses batailles, tu seras retabli à grant honneur et à grant puissance en ton royaulme, car ton corps et ta personne et plus convenable à Mars qu'à Jupiter ni à Venus : et Dieu t'a formi ad ce et sont tes fais dignes de batailles et de ce te portent les hommes temoignage. Il a très redoubté et puissant Prince quant il me souvient que toy conquerant terres deshabitees et pleines de desers en Hybernie, et com̃e le lierre traistre de Lencastre entra en ton royaulme et subvertist les cuers de tes subjes par son faulx art contre toy, tout mon sens s'esment à forsenerie: Et maudite soit l'heure quant il passa en Albion que Neptunus le dieu des vens ne fist ses batailles ou ses voiles non mie au hault pelage de la mer affin que sa nef fut rompue et qu'à celle heure les jours de sa mauvaise et honteuse vie fussent finis et que sa chair fust demourée viande à oyseaux ou aux poissons et son esprit foliable par diverses regions de l'air, et ses os sustraits en la rive de la mer dedans le sablon par le deboutement des eaux. Certes de telles sepultures étaient ils dignes et non d'autre.

"Il a très redoubté Prince l'ardant affection d'amour que tu avois au très faulx Comte de Rotelant t'a ésté molt cher vendue, car par luy seul fut ton passaige de 18 jours d'Hybernye en Angleterre, sans avoir ay nouvelles de tes ennemis par son faulx enginement. Helas et porquoy te Cons tu plus que ceulx de ton conseil qui desiroient molt ta briève retournée. Et certes je m'esnerveille molt coñe les dieux de la mer te furent si fa- 
vorables qui te manderent vent pour arriver au port de' Appleforde. Mielx eust éste pour toy d'estre arrivé d'autre region. Mais ce que est prédestiné du Createur ne peut nul contrester. Encore très redoubté Prince quant il me souvient du Conte de Northomberlant, je maudis sa vie, car il te vint jurer à Cornway sur le corps Nostre Seigneur que ton ennemy Henry de Lencastre ne vouloit que sa terre et qu'il se repentoit de tant qu'il estoit entré en ton royaulme dont je suis molt esbahy comme la terre paternelle le peut soustenir en vie, car toutes ses convenances étoient faulces et plaines de traysons et par icelles t'en mena à Flint avec grant quantité de ses gens d'armes qu'il avoit laissies traiteusement tapis de robes à Cornuay et Rothelant: au quel Chastel de Flint cher sires la nuit te fu molt douleureuse et à bon droit, car tu te veoies environné de tes ennemis de toutes pars, lesquels desiroient ta mort plus que nulle autre chose, et moymême Cuyday à celle heure fermement que la fin de mes jours fust venue, et avoie grant douleur au cuer tant pour toy comme pour moy. Et le lendemain le lierre de Lencastre te emena honteusement à Londres et te livra au turbe lesquels pour leur faux conseil te condamnèrent en chartre perpetuelle dont Notre Seigneur Dieu t'a délivré. Or penser donc de luy rendre graces de ferme entention et ajes vertueuse esperance de prendre vengeance de tes ennemys, et que ce soit par sy grant decision que de leur sang courent fleuves par ton royaulme sy que la fin de leurs douleureux jours soit exemple à tous aultres traitres, à tous temps avenir. Et saichez que touls les maulx et horribles trahisons quilis t'ont faictes j'ay manifestées par figures, par dis au Royaulme de France affin que leur vie soit honteuse et pleine de reproches. Et certes très redoubté Seigneur je ne scais comme la réprésentation de ton image me vient si souvent devant les yeux de mon cueur, car de jour et de nuit toutes mes pensées imaginations ne sont aultres sinon pensées à toy. Et si la voulonté du Createur étoit telle que moy douleureux et triste eusse veu ta figure devant ma mort, tant mon esprit en seroit reconforté : mais combien que je ne la puisse veoir des yeulx de nostre chief sy est-elle tous dis présente devant les yeulx de ma pensée, et m'est aucune fois advis que je te vay et que je parle à toy; ainsy medelictent les fausses joies puisque les vraies je ne puis avoir. Et pour ce je fais sacrifice de foi, d'oraisons et de prières tous les jours de cuer ententif a notre Createur que bien brief je te puisse veoir à telle joye comme je le désire. $O$ très noble Prince et vray Catholique, ayes remembrance de ta noble et loyale compaigne qui espant ses larmes jour et nuyt en toy attendant, desirant oyr vraies nouvelles de ta santé: fais tes mandemens par deça affin qu'il appoire clairement que tu es sain et alegies, car tous hommes nobles et non nobles se rejouissent de ta vie: et n'ayes doleur ni vergongue aucune si ta vengeance n'a ésté faicte des pieça, car tu peux cognoistre clairement les adversités, douleurs et tribulations de cest royaulme, et en espécial de ton beau père Charles Roy de France, et soies ferme et certain que nulle aultre chose ne l'a retardié; et s'il te plaist venir pardeça tu trouveras la plus 
grant partie de la chevalerie preste pour vivre et mourir avec toy et sy trouveras ta noble compaigne que ta belle mère t'a molt précieusement gardée depuis la restitucion . . . . de ton ennemy le lierre de Lencastre lequel delaie sa persecution par l'espèce de 22 mois sans la vouloir rendre. Affin telle qu'elle eust 12 ans accomplis et . . que ce qu'il eust fait faire ou dire eust été ferme et establie : car sa faulce entencion estoit telle de le donner à son fils aisné, lequel tu feis chevalier à grant honneur et à grant joye en Irlande. Mais par ce peut appoir que diligeamment a été requise et sommée par le Conseil de France et tant qu'elle a été rendue ains que le jour de son aage fust accomplié, et sachiez qu'aussy chaste et aussy entière qu'elle étoit partie et tu partis d'elle à Windesore pour aller en ton voyage d'Iyrlande elle est aujourd'hui, et de ce porte ellemême tesmoignage.p Et pour ce très redoubté prince tu dois avoir très grand desir de la veoir, car molt précieuse chose est de cuillir la première fleur du tendre corps de si : able pucelle coñe de ta compaigne. Or viens donceques par deçà chers syres et mets tes voiles en mer, et Ypothades il doulx vent te feira arriver à bon port. Et suis certain que tous les dieulx des vents et de la mer te ferant ton passage et te sera l'estoile d'eau demonstresse de vray port car ta cause apparoit juste à Nostre Seigneur, veu qu'il t'a délivré de sy grant peril auquel tu as ésté molt longuement. Il a, très redoubté Prince, quant nobles dames et chevaliers iront à l'encontre de toy espaudant leurs larmes tant pour la joye de ta santé, comme pour les aimeres fortunes et douleurs que tu as souffertes. Certes, tu veiras tous les hommes louer Nostre Createur et mectre les mains aux armes ententiment pour aler aveque toy contre tes ennemys. Et si tu ne peus venir par deça et qu'aulcun empesche ton passaige, au moins sires qu'il te plaise mander l'étencion de ton couraige et tu trouveras la plus grant partie des nobles du sang de France tes vrays amis et qui ne te fauldront jusques à la mort. Et certes si tu ne viens bien brief pardeça j'iray à toy en quelque lieu que tu sayes, et te porteray par escrit et par figures une grant partie des amères fortunes et dolences coñe je les ny avenir, may estant avecque toy en Hybernie et en Angleterre. Or te prei je, mon très redoubté Seigneur et vray Catholique, en la fin de mon epistre que tu ne la veueille prendre en desdaing, et que la faulte de mon pauvre corps ne te deplaise point et $q$ ententierement et paraventure que tu y trouveras chose qui te pourra aucunement plaire: et sy te promets par Dieu qui est puissant sur toutes creatures que l'ardant desir d'amour que j'ay à toy le me fait desirant de tou mon cuer l'accomplissement de tes bons plaisirs et desirs. Et certes si les dieux de la mer me sont favorables je la suivray tost et iray briefment après.

p Ces lignes prouvent que ceste epitre fut faite avant 1405, epoque du mariage d'Isabelle avec le duc d Orleans.

q Il alla effectivement en Escosse et en fut de retour en 1410. ainsi que l'atteste une quittance donnée par lui Creton le dit au de la somme de 200 francs pour recompense de sa voyage.

vOL. XXViII. 


\section{BALADE PAR LEDIT CRETON.}

$O$ vous Seigneurs du sang royal de France Mettez la main aux armes vistement, Et vous avez certaine cognoissance Du roi qui tant a souffirt de tourment, Far faulx Anglois qui traitreusement Lui ont tollu la domination, Et puis de mort fait condamnation. Mais Dieu qui est le vrai juge es sains cieulx Lui a sauvé la vie main et tant, Chacun le dit par tout jeunes et vieulx C'est d'Albion le noble Roi Richard.

Et s'il est vray pour avoir accroissance De grant honneur faictes hastivement, Vos gens armer, car tante s'esperance Estoit en vous je le sais . . . Car mantis fois pleurant piteusement Luy oy faire en Gales maint renom Du Roi François qui Charles à non, Et de vous touls quant faulx Anglois couculx Le chassoient pleins de couveulx art. C'est grant pitié aidies luy pour le mielx C'est d'Albion le noble Roy Richart.

C'est vostre sang de ligne et d'alliance Chacun le scet et cognoist clairement Vous ne pouvez donc trouver excusance Que ne soiez tenus très grandement De luy aidier n'atendes mandement. Nul quelconque car pour moins d'actroison Tu mis en feu le palais d'Ilion Et Priam mort et quatre de ses fils. Hâtez vous doncque d'envoyer celle part Sy en aurez bon renom en tous lieux C'est d'Albion le noble Roi Richard. 
Princes n'ayes en indignation

S'il ne vous fait de son fait mention

Vous n'en deuez pas être merveilleux

Passez la mer et aydies le Liepart.

Se relever qui est molt doulereux

C'est d'Albion le noble Roy Richart.

La fragilité avecque l'inconstance de la chose publique doit ou doivent désirer par droit cours de nature chief sapient, prudent, et plein de bon gouvernement, et pour ce qu'en ce royaulme le chief principal se peutêtre dolu ou deult encore de bleceure merveilleuse et par avanture incogneue, et peutêtre par la voulenté du Createur, lequel peut avoir ésté ou est indigne aucunement par la multiplicité d'aucuns péchés commis par luy ou par aultres de son royaulme dont punicion lui est transmise de la Majesté Céleste, ou par le péché de nos pères lesquels l'ecriture saincte dit. Nos pères ont péchié mais nous emporterans le mal, ou par avanture aucunes mauvaises oeuvres et detestables faictes par sort ou aultrement . . . . pour le bien publicque très redoubté prince et vray Catholique Philippe fils de Roy de France, duc de Bourgoigne, ${ }^{\mathrm{r}}$ que tu ajes regard à son pauvre et miserable peuple duquel tu as une fois recue la chairge par le consentement et mandement de ton beau frère Charles jadis Roy de France; auquel . . . . . mon très redoubté Seigreur tu as été molt prudent et favorable jusqu'aujourd'hui : et en poursuivant l'œuvre que tu as commencée tu peux estre son seul successeur en terre, car Suetonius dit au livre des xii Cesarres qu'il fut sy habondant en humilité, en chasteté, en sens, en prudence, et en toutes autres operations vertueuses qu'il en passa tous les autres. Ft avecque ce il fu de sy grant cognaissance et especial cultivement de cérémonies aux Dieux que ce fu grant merveille et tant que du commencement de son empire et pris jusqu'à la fin il ne voult souffrir nom d'Empereur ni surnom de Père de Paix, ni à peine vouloit-il souffrir qu'on se agenoillast devant luy, et reprenait aigrement ceulx qui le faisoient et espalmit ceulx qui le blandissoient ou flattoient, et oit-il mortellement laquelle chose est aujourd'huy molt pruchaine collateral et familière d'aucuns grands seigneurs dont est pitié et dommaige. Et par avanture peutêtre qu'aulcuns en perdent la cognoissance d'eulxmelmes il ne faisoit le mal à nul pour chose qu'on dist de luy, feust bien ou mal, mais qu'en franchete toutes laingues devoient être frainches. Il parloit sy bel à chacun et honoroit aussi tous ceulx qui parloient a luy que a pou qu'en ce faisant il ne passoit les mectes d'humanité. Et lors quand les Romains virent son très espécial gouvernement, et qu'il avoit si aspre regart à la chose publique il y ot daucuns ardans en convoitise qui luy conseillerent qu'il creut les threus et redevances du pays, de

r Il etait fils de Jean Roi de France et frère de Charles V. 
quoy il repondit à ceulx molt covreusement qu'ils n'aimoient pas le bien publique, et que ce n'estoit pas fait de bon pastre de vouloir transglantir, ou mengier sa beste, mais de la tondre justement, et tout fist de biens qu'il monstra en luy par exemples coñe chascun se devoit gouverner et vivre. Et pour l'influence des grands biens habondans en ycellui Tybère Cesaire du commencement de son empire jusqu'à la fin, je te puis bien avoir comparé à luy, car encores depuis naguères tu as molt habondamment essuy les vertus de sa succession de tant que tu as voulu demeurer pastour des pauvres bestes comme il fut et n'as pas voulu souffrir leur transglantissement mais as très vigoureusement mis la main aux armes vainqueresses pour les garder. Pour laquelle chose, mon très redoubté Seigneur et vray Catholique, la prudence de toy sera esaucée et divulguée entre tous les Chrestiens de cest monde et entre les aages à venir. Et saichez qu'en faisant telles œuvres tu peux acquerir une vie seconde qui est appellée gloire perdurable, car la gloire qui vault aultant à dire coñe bonne renommée donne à tous prudhommes une vie seconde après la mort, et la renommée qui renaist de leurs bonnes ouvres fait sembler qu'ils soient encores vifs. Encores deffend la gloire que ceulx ne soient mors qui sont dignes de loenges. Et pour ce mon très redoubté Seigneur veuillez soustenir vertueusement le œuvre qu'as commencée, car tes armées ne sont pas aimées ni persecutoires, mais sont doulces et reluisantes comme l'estoile de Jupiter pour le bien publique, et tu le peux appercevoir clairement, car entre tous les aultres princes des Chrestiens tu es désiré en plusieurs lieulx et plusieurs maisons, mesmement des Bretons lesquels singulièrement et seulement à toy veulent baillier toute leur seignorie et garde et governement: laquelle chose est molt honourable veu lat noblesse et force d'iceux et de leur pais. Et pour ce que ta force et puissance est force après celle du chief de ce royaulme surmonte les aultres comme je puis appercevoir qu'il te plaise mectre ententiue à deux choses lesquelles feront vivre ta renommée pardurablement, c'est que tu ayes regard à la très crueuse et miserable discord de nostre mère saincte eglise afin que par toy elle puisse estre unie et mise en paix et en repos, car certes je crois veritablement que touttes les tribulations et maulx qui aucunement ou sont avenus en ce royaulme depuis long temps ne viennent sy non des péchés commis par nous et par la descognoissance ou desobeissance que nous avons de Notre Createur. Molt de beaux exemples lu montre Valerius ou il traite des fais des Romains en disant ainsy. Ce n'est pas merveille si indulgence ou bonne voulenté a été ferme et constante de garder et accroistre l'empire de Rome, lequel a vouler par si scrupuleuse cure estre examinés

s Ce point peut aider à fixer la dâte de la pièce voir en quelle année les Bretons faict cette offre au duc de Bourgogne. Le duc Philippe de Bourgogne fut déclaré regent de Bretagne en 1402, le 19 Octob.

t En 1402 le Pape Benoît XIII. fut assiégé dans le Château d'Avignon par le Maréchal de Boucicault et se sauva déguisé. C'est evidemment à cette epôque qu'il fait allusion. 
les petits meffaits encontre leur honneur ou service; car on ne doit pas cuydier que nostre cité eust oncques les yeulx arrière du très espécial cultivement de cérémonies aux dieux, et ils le monstrèrent bien par plusieurs exemples entre lesquelx je t'en veuille raconter un duquel nous devrions bien en avoir la souvenance. Il fu ordonné à Rome deux Consules dont l'un fu appellé Scipio Nasica et l'autre Gaiyus Siculus, lesquels furent envoyés pour faire guerre l'un en Corsique et l'autre en Gale, lesquelles terres ils soubmirent à la Seigneurie de Rome. Mais non obstant leurs armes vertueuses furent-ils remandés à Rome, et furent privés de leurs estats ou offices pour ce seulement que Tyberius Graccus avoit escript au Collège des Augures à Rome qu'il y avoit fait assemblées de gens dedans le temple ou tabernacle aux dieux pour oyr questions de petites choses et inutiles desquelles la noyse paravanture pouvoit avoir empeschés le sacrifice des dieux. Ceste exemple devrons bien imiter et avoir les saints lieux et esglises en grande révérence, car sy comme dit Ysidore au xv. livre des Thymologies si les paies faisoient aussy grant honneur aux tabernacles ou temples non pas de leurs dieux mais de leurs idoles bien devroient les Chrestiens grant vergaigne avoir de faire se pou de révérence au vray Dieu qui est Nostre Createur. Molt d'aultres grants mistères en racoutent Titus Livius et Valérius Maximus touchant ceste matière, par lesquels il semble qu'ils veulent dire que la grande indulgence et bonne voulente des Romains les dieux ont ésté favourables et aydans. Après mon très redoubté Seigneur veuillez que vengeance ou punicion soit faicte du noble sang du bon Catholique le Roy Richart, lequel a ésté espandu tant villainment tant traicteusement que certes c'est molt misericordieuse et piteuse chose à oyr la fin de ces jours lesquels par la vray et loyal amour qu'il avoit par deça ont ésté finis avant que son aage deust estre accomplie. Helas! si tu sauries bien les tristes complainctes et les piteux regrets qu'il faisoit à tous les Seigneurs du sang de France, et especialement à toy et à Monseigneur de St. Pol, quant il étoit fuitif en Gales pour la craincte des traitres ses ennemis qui le chassaient de toutes parts pour le mettre à mort. Certes tu ferais assembler . . . . . de batailles pour passer en leur ilse; car la longe demeure de paix fait les bons hommes à rudir et devenir paresseux. Et pour ce sires ne soies consentant de leur plus donner treues, mais que vengeance en soit prise telle comme il appartient au meffait. Et vrayment je cuide que depuis le temps que les Gauls detruiserent le souverain empire de Rome, et qu'ils ont passé les Alpes froides rudes et incertables qu'aucun homme paravant n'avoit passées que Hercules seulement, ne fu plus honourable conqueste faicte que ceste, ne dont il fut plus parlé, et ne doubte point leur force forcenée, car nostre Seigneur Dieu qui est vray juge cognoissant leurs maulx, ne les pourroit souffrir ni soustenir les armes victorieuses, comme on le peut clairement appercevoir. Car depuis le temps de leur rebellion, ils n'ont en gaires que fortunes de descomfitures. Et pour ce sires s'il te plâit mectre tes voiles en mer, mais que temps convenable soit venu, et tes enseignes au vent, lesquels 
furent envoyés à ton sang par la puissance divine, tu verras la plus grande partie des nobles hommes mectre la main aux armes ententivement pour aler avecque toy desirant la vengeance du noble sang espandu en Albion. Or te prie je, montrès redoubté Seigneur et vray Catholique, affin de mon epistre que si j'ay aucunement mepris en parler, qu'il te plaise le moy pardonner et supporter l'ignorance de moy qui ne suy que homme lay et pou sachant, et est mon entendement de pou de cognoissance; mais la vraie amour que j'ay à toy le m'a fait faire, desirant de tout mon cuer ton service ycellui Dieu qui ses richesses eslargit et donne habandamment à la vie des saiges te vueille accroier vie victorieuse. Amen.

Ordonnance du Roi Charles VI. pour qu'on donne la somme de 200 francs à Jean Creton, son valet de chambre, pour un Voyage par luifait en Ecosse, afin de savoir si le Roi Richard était en vie, retiré en Ecosse comme on disait.

"Charles, par la grâce de Dieu, Roy de France, à nostre ame et feal chevalier, conseiller, maistre de nostre hostel, Pierre des Essars, prevost de Paris, et souverain gouverneur des finances, des aides, ordonnances pour la guerre, et les généraulx conseillers sur le fait des dis aides. Nous voulons et vous mandons et expressement enjoingnons que par nostre ame Alexandre le Boursier, receueur général d'iceulx aides, vous faictes paier, bailler et delivrer des deniers de sa recette à nostre amé varlet de chambre, Jehan Creton, la somme de deux cens frans, que nous lui avons ordonné et ordonnons par ces présentes prendre et avoir pour une fois des deniers d'iceulx aides, pour et en recompensation d'un Voyaige que par nostre commandement et ordonnance il fist pieca au pays d'Escoce pour savoir et enquerir la vérité de nostre très cher et très ame fils le Roy Richart d'Angleterre que l'on disoit lors estre en vie audict pays d'Escoce, pour lequel voyaige faire nous ne feismes aucune chose pour lors ni depuis audit Creton bailler ne aussi n'a eu de ce de nous aucunes lettres, si comme de ce avons été souffisamment informés. Et par rapportant ces présentes et quittances dudit Creton tant seulement, nous voulons la dite somme de 200 frans estre allouée ès comptes et rabattue de la recette du dit receveur général par nos aamés et feaulx les gens de nos comptes à Paris. Ausquels par ces mesmes lettres mandons que ainsi le facent sans aucun contredit, non obstant quelconques ordonnances, mandemens ou deffences ad ce contraires. Donné à Paris, le 29 jour de Juillet, l'an de grâce mil quatre cent et dix, et de nostre règne le xxx.

" Par le Roy en son conseil, auquel le Roy de Navarre, Messeigneurs les Ducs de Guienne, de Bourgogne, et de Brabant, et autres, estoient,

Bauregart." 
Jehan Creton que le roi avoit envoyê en Ecosse pour savoir si le feu Roi Richard etoit en vie, comme on disait, reconnait avoit reçu la somme de 200 francs pour le dit Voyage.

"Jehan Creton, varlet de chambre du Roy Nostre Seigneur, confesse avoir reçu de Alexandre le Boursier, receveur-général des aides, ordonnances pour la guerre, la somme de cent frans sur la somme de deux cent frans, que le dit seigneur, par ses lettres données le xxix jour de Juillet derrenier passé, lui avoit a ordonné prendre et avoir pour une fois des deniers des dis aides pour et en recompensacion d'un Voiaige que par commandement et ordonnance d'icelui seigneur il fist pieca au pays d'Escoce, pour savoir et enquerir le vérité de feu le Roy Richart d'Angleterre, que l'on disoit estre en vie au dit pays d'Escoce, si comme plus à plein est contenu ès dites lettres. De laquelle somme de cent frans le dit Jehan se tient content etc. quitté etc. promet etc. oblige etc. Fait l'an Mil quatre cens et dix, le Jeudi vii jour d'Aoust.

Toussains. Le Harduin." 